\title{
Unreal Estimates of the Real Rate of Interest
}

\author{
W. W. BROWN and G. J. SANTONI
}

$\mathrm{N}$ the nearly five decades since the publication of Irving Fisher's The Theory of Interest, ${ }^{1}$ economists have engaged in numerous attempts to measure the ex ante real rate of interest. The effort devoted to obtaining these estimates reflects the fact that the ex ante real interest rate conveys information about some fundamental economic relationships. The ex ante real interest rate is the expected net rate of increase in wealth arising from additional investment. Altematively, it can be viewed as the value of present consumption in terms of future income and, consequently, is implicit in the relative price of present consumption in terms of capital goods. Each of these is reconciled with the others by the profit-seeking market activity of individuals. ${ }^{2}$

Like other relative prices, the ex ante real interest rate enters the optimizing calculus of individuals and ultimately affects resource allocation. Each decision an individual makes, to save or invest or to change current consumption relative to either of these, is a choice which, implicitly at least, involves consideration of the ex ante real interest rate.

Changes in the ex ante real interest rate transmit information about changes in the relative values of resources employed in alternative uses and eventually result in a reallocation of resources to higher valued

The authors are associate professors of economics at California State University, Northridge. Santoni is a Visiting Scholar at the Federal Reserve Bank of St. Louis.

Irving Fisher, The Theory of Interest and Capital (New York: Augustus M. Kelley, 1965).

2For a more complete discussion see Armen Alchian and William Allen, Exchange and Production: Competition, Coordination and Control (Belmont, Calfformia: Wadsworth, 1977), pp. $435-36$. uses. Changes in this interest rate reflect changes in the net demand for present consumption goods relative to future consumption goods. The allocation of present resources to the production of these goods will be redirected in response to the change in their relative values.

Since all goods are more or less durable (i.e., they yield consumption streams which persist over varying lengths of time), the reallocation of present resources resulting from a change in the ex ante real interest rate will pervade all markets. In the absence of information about the movement of the ex ante real interest rate, it is difficult to distinguish "disturb. ances" (resource reallocation) induced by shifts in the demand for present consumption goods relative to future consumption goods from those caused by shifts in aggregate demand for both present and future goods. From the point of view of the policymaker, the distinction is crucial. If the disturbance is the result of a shift in relative demands, resources will be reallocated to higher-valued uses and community net wealth will rise. If the disturbance is the result of a shift in aggregate demand, any temporary reallocation of resources occurring during the disturbance must be to lower-valued uses causing community net wealth to fall. Policymakers might wish to eliminate the latter result but should not attempt to retard the former.

While information about changes in the ex ante real interest rate is valuable to the policymaker, it is difficult to obtain. The ex ante real interest rate reflects the expectations of individuals regarding fature events. As such it can not be directly observed. It is, of course, possible (and inexpensive) to observe the 
consequences of decisions that are made on the basis of these expectations. The wealth consequences associated with any economic decision can always be calculated after the fact. However, this ex post real rate of retum does not bear on economic decisions since it is only known after these decisions have been made. Unlike the ex ante real rate of interest, the ex post real rate of return is irrelevant to the process of resource allocation.

Since the ex ante real interest rate can not be observed directly, individuals interested in estimating its magnitude have been led to employ the simple Fisherian relationship that the nominal (market) rate of interest is equal to the sum of the ex ante real rate of interest and the anticipated rate of inflation in the general level of prices. The relationship implies that empirical estimates of the ex ante real interest rate can be obtained by subtracting some measure of the anticipated rate of inflation in the general level of prices from the nominal rate of interest. As a result, previous estimates of the ex ante real interest rate have turned on the complicated problem of measuring the anticipated rate of inflation.

Virtually all previous studies have dealt with this problem by modeling the anticipated rate of inflation in the general level of prices as some function of past changes in the consumer price index (CPI) or GNP deflator. ${ }^{3}$ If the real rate of interest is not changing, this method may produce "reasonably" accurate estimates of the anticipated rate of inflation in the general level of prices. Unfortunately, if the real rate of interest is itself changing, these commonly used price indices will produce biased estimates of actual changes in the general level of prices. Consequently, use of these indices to proxy expected future price level

\footnotetext{
3Recent examples include Albert E. Burger, "An Explanation of Movenents in Short-Term Interest Rates," this Revieto (July 1976), pp. 10-22; fohn A. Carlson, "Short-Term Interest Rates as Predictors of Inflation: Comment," American Economic Review (fune 1977), pp. 469-75, Michael Echols and Jan Walter Elliot, "Rational Expectations in a Disecuilibrium Model of the "Term Structure," American Economic Review (March 1976), pp. 28-44; Jan Walter Elliot, "Measuring the Expected Real Rate of Fnterest: An Exploration of Macroeconomic Alternatives," American Economic Review (Jume 1977), pp. 429-44; Eagene F" Fama, "Short-T"erm Interest Rates as Predictors of Inflation," American Economic Review (Ime 1975), pp. 269.82; Eugene F. Fama, "Inflation Uncertainty and Expected Returms on Treasury Bills," Joumal of Poltical Economy (June 1976), pp. 427-48; Martin Feldstein and Otto Eckstein, "The Fundamental Determinants of the Interest Rate," The Review of Economics and Statistics (November 1970), pp. 363-75; P. I. Hess and J. L. Bicksler, "Capital Asset Prices Versus 'Time Series Models as Predictors of Inflation," Joumal of Financial Economics (December 1975), pp. 341 60; Williarn P. Yohe and Denis S. Karrosky, "Interest Rates and Price Level Changes, 1952-1969," this Review (December 1969), pp. 18m38.
}

changes in Fisher's equation will prejudice measturement of both the level and direction of movement of the real rate of interest. ${ }^{4}$

This particular problem arises in a number of recent articles dealing with the inflationary period since the late 1960s which have reported sharply declining and negative $e x$ ante real rates in 1974 and $1975^{5}$ The theoretical possibility of a negative ex ante real rate of interest is not at issue here. ${ }^{6}$ Casual observation suggests that the preconditions for a negative $e x$ ante real interest rate do not now exist, nor did they exist in 1974 and 1975..$^{7}$ More importantly, however, sharply declining ex ante real rates imply specific kinds of economic adjustments which were contrary to those that actually occurred during this period.

The purpose of this article is to demonstrate that the estimates of the ex ante real rate obtained by these previous studies are spurious. Following Alchian and Klein, ${ }^{8}$ it is first demonstrated that, when real rates of interest are rising, commonly used price indices will overstate changes in the general level of prices. This introduces a downward bias into estimates of the real rate of interest when the estimates depend on measured changes in these price indices. Secondly, evidence is presented which indicates that the ex ante real rate of interest increased during

\footnotetext{
4This bias exists apart from the tax and uncertanty effects noted by others. See, for example, James E. Pesando and L. Smith, "Tax Effects, Price Expectations and the Nominal Rate of Interest," Economic Inquiry (Jume 1976), pp. 259-69; Michael Darby, "The Financial and Tax Effects of Monetary Policy on Interest Rates," Economic Inquiry (June 1975), pp. 226-76, Y. Amihud and A. Bamea, "A Note on Fisher Hypothesis and Price Level Uncertainty," Journal of Financial and Quantitative Analysis (September 1977), pp. 525-29.
}

5See for example Elliot, "Measuring the Expected Real Rate of Interest: An Exploration of Macroeconomic Alternatives;" Fama, "Interest Rates as Predictors of Inflation;" Hess and Bicksler, "Capital Asset Prices Versur Time Series Models as Predictors of Inftation" Pesando, "On the Efficiency of the Bond Market: Some Canadian Evidence," Journal of Political Economy (December 1978), pp. 1057-76.

- Like Fisher, who discusses negative rates in the context of shipwrecked sailors whose store of figs is deteriorating, we think that "The fact we seldom see an example of zero or negative interest rates is because of the accident that we happen to live in an enviromment so entirely different..." (Fisher, The Theory of Interest and Capital, p. 192).

"Such preconditions would imply “. . . a world in which the only provisioning for the future consisted in carrying over inital stocks of perishable food, clothing and so forth and if every unit so carried over into the future were predestined to melt away. .. " (Fisher, The Theory of Interest and Capital, p. 91).

8 Armen Alchian and Benjamin Klein, "On a Correct Measure of Inflation," Journal of Money, Credit and Banking (February 1973), pp. $173-91$. 
1974-1975. These results suggest that the previously reported falling and/or negative estimates of the ex ante real rate are statistical artifacts. To put it directly, they are nothing more than the predictably spurious consequences of the method used to generate them.

\section{MEASUREMENT OF TIE REAL RATE}

The methodology commonly used in measuring the real rate of interest is represented by the following three equations:

(1) $\mathrm{r}=\mathrm{i}-\mathrm{Pe}$

(2) $\hat{\vec{P}}_{\mathrm{e}}=\mathrm{f}(\mathrm{C}), \mathrm{f}^{\prime}>0$

(3) $\hat{i}=i-\hat{p}_{\mathrm{e}}$.

Equation 1 states the familiar theoretical relationship developed by Fisher between the ex ante real rate of interest $(x)$, the observed nominal rate of interest (i) and the anticipated future rate of inflation $\left(P_{4}\right)$, assuming continuous compounding. Equation 2 characterizes the methodology commonly employed in estimating the anticipated rate of inflation. It indicates that estimates of the anticipated future rate of inflation $\left(\hat{\mathrm{P}}_{\mathrm{e}}\right)$ are obtained from observation of past changes in some price index $(\mathrm{C}) .^{9}$

Finally, equation 3 states that estimates of the ex ante real rate $(\hat{r})$ are derived by subtracting $\hat{P}_{a b}$ from the observed nominal rate of interest.

Since neither $\mathrm{F}$ nor $\mathrm{P}_{\mathrm{f}}$ is directly observable, the validity of this process for accurately estimating the

\footnotetext{
The index most frequently used is the CPI. See Burger, "An Explanation of Movements in Short-Term Interest Rates;" illiot, "Measuring the Expected Real Rate of Interest: An Exploration of Macroeconomic Alternatives;" Fama, "Intlation Uncertainty and Expected Returis on Treasury Bills;" Hess and Bicksler, "Capital Asset Price Versus Time Series Models as Pedictors of Inflation;" Yohe and Karnosky, "Interest Rates and Price Level Changes, 1952-1969." The GNP deflator has been used less frequently. See Feldstein and Eckstein, "The Fundamental Deteminants of the Interest Rate." The wrocedure used to estimate expected inffation for period $t$ from the observation of past levels of some price index is, roughly, the following: An estimate of the period $t$ price level is made in period $t-1$. This estimate is a weighted average of past price levels. That is,

$\hat{\mathrm{C}}_{t}=\sum_{t=t-1}^{\mathrm{t}-\mathrm{n}} \mathrm{W}_{\mathrm{i}} \mathrm{C}_{1}$

where the lefthand term is the estimate and the $W$ are the weights assigned to past price levels. The estimated change in the price level is obtained by subtracting the price level in period t... from the estimate for period t as follows

$\Delta \hat{\mathrm{C}}_{\mathrm{t}}={ }_{\mathrm{t}-1} \hat{\mathrm{C}}_{\mathrm{t}}-\mathrm{C}_{\mathrm{t} \cdots 1}$.

Last, the estimated change in the price level is defined to be the estimate of expected intation for period $t$,

$\Delta \hat{\mathrm{C}}_{\mathrm{t}}=\hat{\mathrm{P}}_{\mathrm{e}_{\mathrm{r}}}$.
}

ex ante real rate depends crucially on whether $\hat{\mathrm{P}}_{\mathrm{i}}$ is a reliable proxy for $P_{i}$. Typically, $\hat{P}_{i}$ is regarded as "good" or "bad" depending on how well it predicts the actual contemporaneous rate of change in the particular price index being used. The implicit assumption is, of course, that contemporaneous changes in the index reflect true changes in the general level of prices.

Fama's justification of his use of the CPI is fairly typical. He comments:

The Burean of Labor Statistics Consmer Price 1 m. dex $(\mathrm{CPI})$ is used to estimate $\triangle \mathrm{P}$, the rate of change in the purchasing power of money from the end of month $t-1$ to the end of month $t$. The use of ary index to measure the level of prices of consumption goods can be questioned. There is, however, no need to speculate about the effects of shortcomings of the data on the tests. If the results of the tests seem meaningful, the data are probably aclequate."

Several authors have questioned whether functions of past rates of change in the CPI, or GNP deflator, serve as reliable predictors of expechations regarding future price level change." Others have commented on how measurement errors in the indices must be taken into account when estimating real interest rates. ${ }^{12}$ None, however, have tried to confirm the validity of the estimates by observing economic relationships known to depend on the real rate of interest.

Alchian and Klein have noted a significant difficulty in using changes in common price indices as measures of changes in the general level of prices, or "purchasing power of money." In particular, they argue that changes in the purchasing power of money are determined by changes in the prices of both present consumption goods and long-lived assets, not just changes in the prices of present consumption goods alone. They comment:

The analysis, , bases a price index on the Fish. erian tradition of a proper defnition of intertemporal consumption and leads to the concluston that a price

"Fama "Short-Term Interest Rates as Predictors of Inflation," p. 247.

"See Carlson, "Short-Tem Interest Rates as Predictors of InHation," Edkard J. Kane and Burton G. Malkiel, "Antoregressive and Nonautoregressive Elenents in Cross-Section Forecasts of Inftation," Econometrica (January 1976), pp. I-16.

1. See Fama, "Inflation Uncertainty and Expected Returns on Treasury Bills;" Feldstein and Fokstein, "The Fundamenal Deteminants of the Interest Rate;" Kane and Malkiel, "Autoregressive and Nonautoregressive Elements in Cross-Section Forecasts of Inflation:" C. Netsor and G. Schwart, "ShortTerm Interest Rates as Fredictors of Inflation: On Testing the Hypothesis that the Real Rate of Interest is Constant, American Economic Review (Jume 1977), pp. 478-86. 
index used to measure inflation must include asset prices (italics added), A correct measure of changes in the nominal money cost of a given utility level is a price index for wealh. If monetary impulses are transmitted to the real sector of the economy by producing transient changes in the relative prices of service flows and assets, (i.e., by producing short-rum changes in the real rate of interest), then the commonly used, incomplete, current flow price indices provide biased short-run measures of changes in the 'purchasing power of money.'is

The CPI and GNP deflator largely exclude the prices of long-lived goods and existing capital assets. ${ }^{14}$ Consequently, changes in these price indices will depend on changes in the real rate of interest because of the well-known difference in the interest elasticities of the market prices of short- and long-lived goods.

\section{THE MEASUREMENT POPOLEM}

Our criticism of the methodology currently used to measure the ex ante real rate of interest rests on two interrelated points. First, the quantity weights used in calculating the CPI and GNP deflators do not accurately reflect the mix of goods actually available to individuals. As a result, changes in these commonly used price indices produce biased estimates of actual changes in the general level of prices when the real interest rate is changing. Second, given that it is the expectation of market participants concerning the future rate of inflation in the general level of prices that is relevant in Fisher's theory of the nominal rate of interest, estimates of the real interest rate that employ past changes in a commonly used price index as a proxy for expected inflation will be biased when the real rate is changing. Each of these points is demonstrated below.

\section{Point 1: Changes in the General Level of Prices versus Changes in Commonly Used Price Indices}

Assume initially that an increase in the real rate of interest occurs and that both the quantity of money and its velocity are unchanged. ${ }^{15}$ If the quantity of

\footnotetext{
13 Alchian and Klein, "On a Correct Measure of Inflation," p. 173 .

1tDurable goods have a weight of 18.75 percent in the CPI. Nondurable goods and services have weights of 47.19 and 34.03 percent, respectively. See Bureat of Labor Statistics, Handbook of Methods, Bulletin 1910, 1976. The GNP deflator includes the prices of currenty produced capital goods but it excludes the prices of existing capital assets.

15 Economic theory suggests that velocity will rise with an increase in $r$. This is discussed below.
}

output is also unchanged, there will be no change in the general level of money prices or the level reflected in a Fisherian price index (i.e., one which includes asset prices). However, since the prices of shortlived goods rise relative to the prices of long-lived goods when the real interest rate rises, the money prices of short-lived goods (long-lived goods) will rise (fall) relative to the general level of money prices. Thus, when the real interest rate is rising, commonly used price indices, in which the prices of short-lived goods receive a relatively heavy weight, will rise introducing a systematic upward bias into the estimation of changes in the general level of prices. The reverse holds when the real interest rate falls.

If an increase in the real interest rate produces an increase in the general level of money prices through a once-and-for-all rise in velocity, the resulting increase in commonly used price indices will contain two components: 1) an increase due to the rise in the general level of prices and 2) an increase due to the bias introduced by capturing only part of the price changes that have occurred. However, wealthmaximizing market participants will ignore both of these components in forming their expectation regarding the future rate of inflation in the general level of prices. They will ignore the first component because it represents a once-and-for-all change which leaves the future rate of inflation unaffected. They will ignore the second component because its effect is to overstate the true change in the general price level. On the other hand, estimates of price expectations that employ the common methodology (the ability to reproduce actual changes in the CPI) will include both.

This argument can be presented more formally. Assume there are two kinds of goods - short-lived, $Q^{s}$, and long-lived, $Q^{\mathrm{L}}$ - and money. Suppose, in the base period, the real rate of interest is $r_{6}$. Then,

(4) $\mathrm{M}_{0} \cdot \mathrm{V}_{\mathrm{a}}=\mathrm{P}_{0}^{\mathrm{s}} \cdot \mathrm{Q}_{\mathrm{a}}^{\mathrm{s}}+\mathrm{P}_{0}^{\mathrm{I}} \cdot \mathrm{Q}_{0}^{\mathrm{L}}$

where $M_{0}$ is the money supply, $V_{0}$ is velocity, and $P_{0}^{s}$ and $P_{0}^{\mathrm{L}}$ are the prices of short- and long-lived goods, respectively.

If the interest rate increases to $r_{1}$, velocity will rise as relative prices change. ${ }^{1 "}$ Let

\footnotetext{
16Quantities will eventually adjust as well but that is ignored here. In any case the quantity adjustment which takes place makes no difference for the measurement of the change in a fixed weight index.
} 
(5) $\quad \mathrm{F}_{1}=\frac{\mathrm{P}_{1}^{\mathrm{S}} \cdot \mathrm{Q}_{0}^{\mathrm{g}}+\mathrm{P}_{1}^{\mathrm{L}} \cdot \mathrm{Q}_{0}^{\mathrm{L}}}{\mathrm{P}_{0}^{\mathrm{S}} \cdot \mathrm{Q}_{0}^{\mathrm{g}}+\mathrm{P}_{0}^{\mathrm{I}} \cdot \mathrm{Q}_{0}^{\mathrm{L}}}$

represent the level of a Fisherian price index in the current period. If the change in the interest rate was the only change that affected the index between the base and current period, the change in the Fisherian price index is

(6) $\Delta F=F_{1}-1$

Let

$$
\mathrm{C}_{1}=\frac{\mathrm{P}_{1}^{\mathrm{s}} \cdot \mathrm{Q}_{0}^{\mathrm{s}}}{\mathrm{P}_{\mathrm{s}}^{\mathrm{s}} \cdot \mathrm{Q}_{0}^{\mathrm{s}}}
$$

represent the level of a commonly used price index in the current period. It differs from the Fisherian index in that it excludes prices of long-lived goods. The change in this price index, due to the change in $r$ occurring between the base period and the current period, is

(8) $\Delta \mathrm{C}=\mathrm{C}_{1}-1$.

It is a simple matter to show that an increase in the real rate of interest will have a greater effect on the commonly used price index than on the Fisherian price index. We know that

\section{(9) $\mathrm{P}_{\mathrm{E}}^{\mathrm{g}} / \mathrm{P}_{1}^{\mathrm{L}}>\mathrm{P}_{\mathrm{D}}^{\mathrm{S}} / \mathrm{P}_{0}^{\mathrm{t}}$}

because a rise in the real rate of interest increases the price of short-lived goods relative to long-lived goods. Now consider the Fisherian index which can be written as

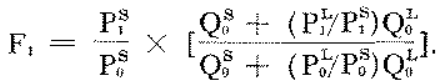

'That is,

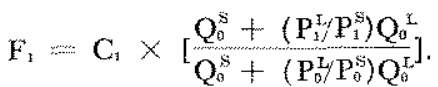

The term in the brackets is less than one since, from (9),

$\mathrm{P}_{1}^{\mathrm{E}} / \mathrm{P}_{x}^{\mathrm{S}}<\mathrm{P}_{0}^{\mathrm{L}} / \mathrm{P}_{0}^{\mathrm{S}}$

and thus

$\mathrm{Q}_{\mathrm{B}}^{\mathrm{S}}+\left(\mathrm{P}_{1}^{\mathrm{L}} / \mathrm{P}_{\mathrm{L}}^{\mathrm{S}}\right) \mathrm{Q}_{0}^{\mathrm{L}}<\mathrm{Q}_{0}^{\mathrm{B}}+\left(\mathrm{P}_{0}^{\mathrm{L}} / \mathrm{P}_{0}^{\mathrm{S}}\right) \mathrm{Q}_{0}^{\mathrm{L}}$

It follows that $\mathrm{F}_{1}<\mathrm{C}_{1}$ and $\Delta \mathrm{F}<\Delta \mathrm{C}$.

In general, when the real interest rate is increasing, use of price indices that are based primarily on shortlived goods will introduce a systematic upward bias into estimation of changes in the general level of prices (in the Fisherian sense). The reverse is true during periods of decline in the real interest rate. ${ }^{17}$

17nterestingly, Alchan and Klein commented on this source of inherent measurement error in the CPI and GNP de-

\section{Point 2: Biased Estimates of the Real Interest Rate}

If $\mathrm{r}$ remains unchanged, changes in commonly used price indices accurately reflect changes in a Fisherian index of prices. Consequently, the methodology summarized in equations 1-3 will yield accurate estimates of $\mathrm{r}$ for such periods. However, dming periods in which $r$ is changing, bias in the common price indices introduces, through equations 2 and 3, bias into any estimate of the real interest rate that employs these indices.

To demonstrate this second point, ignore other factors that affect common price indices (e.g, a change in the monetary growth rate) and express $\mathrm{C}$ as a function of the real rate of interest. That is,

(10) $\mathrm{C}=\emptyset(\mathbf{r}), \phi^{\prime}>0$

The error generated in estimating the real interest rate by the method employed in the studies refer. enced earlier is given by

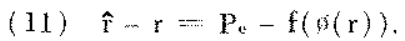

The error in estimated changes in the real rate is obtained by differentiating equation 11 with respect to $r$ In doing $s o$, note that the price expectations $\left(P_{3}\right)$ of market participants are based upon the anticipated future rate of change in the general level of prices in the sense of Fisher's theory and not upon onceand-for-all changes produced by changes in $r$. Hence, price expectations will be unaffected by changes in $\mathrm{I}$ while the estimate of price expectations will vary positively with such changes. That is,

(12) $\frac{\mathrm{d} \hat{\mathrm{r}}}{\mathrm{dr}}=1-\frac{\partial \mathrm{f}}{\partial \theta} \frac{\partial \emptyset}{\partial \mathrm{r}}$.

The term $\partial f, \partial \phi$ is always positive. Estimates of $\overline{\partial \phi} \quad \partial \mathrm{r}$

changes in the ex ante real rate of interest will always understate any actual change that occurs.

Even worse, the procedure employed in previous work can err in assessing the direction of change in the real rate. If the effect of a change in the interest rate on the commonly used price index described in

lator, but did not parsue its implications for estimating the real rate of interest. They remakk: "It should be moted that athough ou disenssion emphasizes that movements in asset and serviee prices difer largely beanse of diftering rates of adjustment to cyclical monetary disturbanes there may also be a significant secular bias due to changing ectuilibrim real asset yields. (The apparent increase in real rates of interest over the years is ignored in our discussion.)" Alchan and Klein, "On a Corred Neasure of Infation," p. 180. 


\section{Table 1}

\section{Selected Estimates of the Real Rate of Interest}

\begin{tabular}{|c|c|c|c|c|}
\hline Year & $\begin{array}{l}\text { Elliol } \\
\text { short-term }\end{array}$ & $\begin{array}{l}\text { Carlson } \\
\text { T bill rate }\end{array}$ & $\begin{array}{l}\text { st Louis fed } \\
\text { yield on high } \\
\text { grade corp bonds }\end{array}$ & $\begin{array}{l}\text { Ex post: } \\
\text { short-tern }\end{array}$ \\
\hline 1970 & $0.57 \%$ & $238 \%$ & $286 \%$ & $258 \%$ \\
\hline 1971 & 1.69 & 1.05 & 2.18 & 2,02 \\
\hline 1972 & 213 & 1,28 & 272 & 2.52 \\
\hline 1973 & 1.07 & 2.35 & 2.84 & 2,10 \\
\hline 1974 & 0,41 & 0.40 & 178 & 0,28 \\
\hline 1975 & 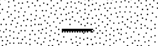 & 0.07 & 0,05 & 2,25 \\
\hline
\end{tabular}

The nutered ate we report is the anmeal average of the various subpenods h, the case of

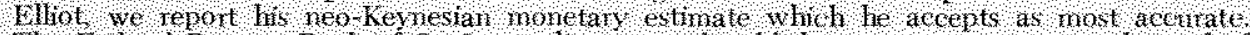
The rederd Reserve Bank of St Lows disconthned publshing estinates, pris to the end of 1975. The estimate we attribute to them for 1975 s one that we calculate using then nethod of estimation:

equation 12 is sufficiently large, $\mathrm{d} \hat{\mathrm{r}}$ will be negative.

$$
\overline{\mathrm{dr}}
$$

Hence, even though the change in the real rate is positive, the estimated change could be negative. This may explain the declining estimated real rates reported for the mid-1970s.

\section{EVIDENCE ON CHANGES IN THE REAL RATE}

Table 1 presents some previously reported estimates of the ex ante real rate of interest from 1970 to 1975. Additionally, it presents the difference between current short-term market rates and contemporaneous rates of change in the CPI. The latter would represent the "true" ex post yield if changes in the CPI measured changes in the general level of prices without error.

All of these estimates show dramatic declines in 1974 and 1975, years in which substantial increases were recorded in the CPI. Elliot's reaction to his results is perhaps typical. He asserts:

. . some relationship appears to exist between the temporal pattern of the real rate and the chrrent rate of inflation. . . The regative and statistically signif. cant nature of this relationship suggest that experted real rates are systematically lowered when the most current realized rate of inflation is increasing, ${ }^{18}$

18Elliot, "Measuring the Expected Real Rate of Interest: An Exploration of Macroeconomic Altematives, p. 442. For similar statements see Carlson, "Short-Term Interest Rates as Predictors of Intlation: Comment," p. 472; Feldstein and
However, before concluding that changes in the CPI affect the real rate of interest, it seems appropriate to determine whether other evidence is consistent with this hypothesis. Changes in the ex ante real rate of interest imply specific behavior in the prices of long-lived assets relative to the prices of short-lived assets. Falling real rates of interest in 1974 and 1975 should have been accompanied by a rise in the present prices of long-lived assets (which produce future consumption services) relative to the prices of shortlived goods. Evidence indicates, however, that the relative price of long-lived assets fell during 1974 and 1975 . This evidence is inconsistent with the contention that the ex ante real rate of interest declined precipitously during this period.

\section{SOME EVIDENCE FROM INDIVIDUAL MARKETS}

The movement of relative prices in various markets is examined below. As noted earlier, a change in the ex ante real rate of interest shows up as a change in the relative price of less durable (present) goods in terms of more durable (capital) goods. An increase in the ex ante real rate of interest reflects an increase in the demand for present goods relative to capital goods. Consequently, the price of present goods in terms of capital goods will rise. This adjustment in relative prices mirrors the change in the ex ante real interest rate.

Eckstem, "The Fundamental Determinants of the Interest Rate," p. 366; Yohe and Karnosky, "Interest Rates and Price" Level Changes, 1952-1969," p. 24 and p. 26. 
By its nature, this type of evidence requires examination of price movements in individual markets. This procedure of examining relative price movements is always open to the charge that any observed relative price change in an individual market may be due to circumstances unrelated to a change in the ex ante real interest rate. As was noted previously, however, a change in the ex ante real interest rate pervades all markets. If an examination of a number of markets reveals that the price of the less durable good has consistently moved in the same direction relative to the price of the more durable good, the contention that the observed change in relative price is due to the impact of special circumstances in each of these markets loses much of its force.

Since the ex ante real interest rate can not be directly observed, any evidence about its magnitude or direction of change will always be circumstantial. The evidence presented below is no exception. However, as Thoreau has noted, "( $s$ )ome circumstantial evidence is very strong, as when you find a trout in the milk."

The evidence presented below is reasonably consistent across the various markets for the 1968-1975 period. Moreover, changes in the price ratios examined correspond perfectly across markets for the 1972-1975 period. However, the direction of change in the ex ante real interest rate implied by these price ratio changes occurring during the later period contradicts that reported in previous studies. This contradiction is perhaps not surprising. We have shown that past increases in the real rate will introduce a downward bias into estimates of the present change in the ex ante real interest rate. Examination of changes in the price ratios occurring in all four markets indicates an increase in the ex ante real interest rate in the two years immediately preceding 1974. Three of the four markets indicate an increase in the real rate in the three years immediately preceding 1974 . The above contradiction is the "trout" whose presence is verified by this evidence.

1. The Commodity Markets: Changes in the real rate of interest will be reflected in changes in spot relative to futures prices. The spot price of a good is today's price for delivery today while the futures price is today's price for delivery in the future. A decrease in the real rate must be reflected in a decrease in the value of present (spot) goods relative to future goods. Spot prices will fall relative to futures prices when the ex ante real rate of interest falls.

Between 1960 and 1972 the average annual ratio of
Table 2

\section{Spot and Futures Prices $1924-1926=100$}

\begin{tabular}{cccc}
\hline Index of & $\begin{array}{c}\text { Index of } \\
\text { spot prices }\end{array}$ & $\begin{array}{c}\text { Ratio of spot } \\
\text { prices to } \\
\text { futures prices } \\
\text { futures prices }\end{array}$ \\
\hline 1960 & 141.80 & 141.22 & 1.004 \\
1961 & 149.85 & 148.44 & 1.009 \\
1962 & 149.85 & 143.90 & 1.041 \\
1963 & 159.83 & 154.49 & 1.034 \\
1964 & 142.99 & 136.82 & 1.045 \\
1965 & 142.47 & 139.31 & 1.022 \\
1966 & 139.44 & 136.71 & 1.019 \\
1967 & 142.88 & 141.79 & 1.007 \\
1968 & 144.45 & 143.26 & 1.008 \\
1969 & 144.90 & 139.10 & 1.041 \\
1970 & 145.07 & 144.81 & 1.001 \\
1971 & 144.35 & 146.30 & .986 \\
1972 & 189.49 & 184.58 & 1.026 \\
1973 & 340.51 & 320.50 & 1.062 \\
1974 & 384.53 & 357.26 & 1.076 \\
1975 & 296.33 & 287.88 & 1.029 \\
& & & \\
\hline
\end{tabular}

SOULCE: The Dow Jones Commodities Handbook, Dow Jones Company, New York 1977, pp. 178-179.

the Dow Jones index of spot prices to the Dow Jones index of futures prices was 1.019 , with a standard deviation of .018 (see table 2). Between 1973 and 1975 this ratio averaged 1.057 . In 1974 , when previous studies report a precipitous decline in the real rate (see table 1), the ratio reached its highest level (1.076) in the entire 16-year period. Relative price behavior in the commodities markets is inconsistent with a falling ex ante real rate of interest in 1974 and 1975 .

2. Durable and Nondurable Goods: Durable goods, by definition, embody a longer-lived stream of future services than do nondurable goods. Therefore, falling real rates of interest imply a decrease in the price of nondurable goods relative to the price of durable goods.

From 1960 to 1972 the average ratio of the U.S. Bureau of Labor Statistics' index of nondurable goods prices to its index of durable goods prices was .976 (table 3), with a standard deviation of 040 . Between 1973 and 1975 it averaged 1.122. In 1974 it was 1.156 . Again, this relative price behavior is inconsistent with 


\section{Table 3}

\section{Nondurable and Durable Goods Prices}

\begin{tabular}{|c|c|c|c|}
\hline Year & $\begin{array}{l}\text { Index of } \\
\text { nondurable } \\
\text { goods pitces }\end{array}$ & $\begin{array}{l}\text { nodex of } \\
\text { durable, } \\
\text { goods prices }\end{array}$ & $\begin{array}{l}\text { Ratlo of } \\
\text { nondurable } \\
\text { goods prices } \\
\text { to durable } \\
\text { goods prices }\end{array}$ \\
\hline 1060 & 89.4 & 96.7 & 924 \\
\hline 1961 & 00.2 & 96.6 & .933 \\
\hline 1962 & 909 & 976 & 924 \\
\hline 1963 & 920 & 979 & 939 \\
\hline 1964 & 93,0 & 988 & 941 \\
\hline 1965 & 94.6 & 984 & 961 \\
\hline 1966 & 98.1 & 98.5 & 995 \\
\hline 1967 & 1000 & 1000 & 1000 \\
\hline 1968 & 103.9 & 103, & 1007 \\
\hline 1969 & 1009 & 1070 & 1017 \\
\hline 1970 & 1140 & 1118 & 1010 \\
\hline 1971 & 1171 & 1165 & 1010 \\
\hline 1972 & 1217 & 180 & 1023 \\
\hline 1073 & 132.8 & 1219 & 1,089 \\
\hline 1974 & 151.0 & 130.6 & 1156 \\
\hline 1975 & 163.2 & 1455 & 1,121 \\
\hline 1976 & 169.2 & 154,3 & 1097 \\
\hline 1977 & 1789 & 1632 & 1096 \\
\hline 1978 & 1920 & 1739.9 & 1,105 \\
\hline
\end{tabular}

SOURCE Department of Labo, Buncan of Labor Statistics, Consumer Prce Index Speeial Indexes

the dramatic decline in the real rate suggested by the estimates in table 1.

Furthermore, the estimates in table 1 do not appear to be appropriately related to relative prices over extended periods. If estimates generated by the standard method track the real rate, they should be positively correlated with the relative price ratios. This is not the case, however, between 1960 and 1975. The correlation between Elliot's estimates and the ratio of nondurable prices to durable prices is $-6,625$. Between his estimates and the ratio of spot and futures prices, the correlation is -.484 . The corresponding coefficients for Carlson's estimates are -.459 and -.073 . Those for the St. Louis Fed are -.692 (significant at the 5 percent level) and -.121 .

None of these estimates of the ex ante real rate of interest generated by the standard method moved in the direction implied by movements in these relative
Table 4

\section{Ratios of Earnings/Stock Prices and Price of Nondurable Goods/ Stock Prices}

\begin{tabular}{|c|c|c|c|}
\hline Year & $\begin{array}{l}\text { Standardand } \\
\text { Poor's Stock } \\
\text { Pilce Index }\end{array}$ & Earnings $\mathrm{Prlce}$ & $\begin{array}{l}\text { Ratio of } \\
\text { nondurable } \\
\text { goods prices } \\
\text { to stodk } \\
\text { prices }\end{array}$ \\
\hline 1960 & 558 & 5,90 & 161 \\
\hline 1961 & 66.2 & 462 & 136 \\
\hline 1962 & 624 & 582 & 1.45 \\
\hline 1963 & 69.9 & 550 & 131 \\
\hline 1964 & 814 & 5.32 & 114 \\
\hline 1966 & 88.2 & 5.59 & 1,07 \\
\hline 1966 & 853 & 6,63 & 115 \\
\hline 1967 & 920 & 573 & 100 \\
\hline 1968 & 987 & 5,67 & 1.05 \\
\hline 1969 & 978 & 608 & 1,11 \\
\hline 1970 & 83.2 & 6.46 & 1,37 \\
\hline 1971 & 98.3 & 541 & 119 \\
\hline 1972 & 109.2 & 5.50 & 181 \\
\hline 1973 & 1074 & 7.12 & 123 \\
\hline 1974 & 82.8 & 11.60 & 182 \\
\hline 1975 & 862 & 912 & 189 \\
\hline 1976 & 1020 & 8.90 & 1,66 \\
\hline 1977 & 98.2 & 10.80 & 182 \\
\hline 1978 & 96.0 & 1205 & 2,00 \\
\hline
\end{tabular}

Standard and Poor's Statestical Soryce, Secunity Price Index Feoord, Standard and Poors Cononation, New York XY.

prices during the $1969-1975$ period. The correlations suggest that the effect $\partial f$. $\partial \theta$ described in equation

$$
\partial \phi \quad \partial \mathrm{r}
$$

12 may be sufficiently large to make dr̂ negative.

$$
\overline{d r}
$$

3. The Stock Market: The stock market provides further evidence on this issue. Because stock prices represent the present value of expected future earnings, a decrease in the ex ante real rate of interest will be reflected by a rise in the price of shares relative to current earnings and a fall in the earnings to price ratio. During the period $1960-1972$, earnings to price ratios averaged 5.709 (table 4 ) with a standard deviation of .511. In 1974 and 1975 , earnings to price ratios reached levels of 11.60 and 9.12 , respectively. 
In addition, a decrease in the rate of interest will be reflected by a fall in the price of nondurable pres. ent consumption goods relative to stock prices. Between 1960 and 1972 the ratio of the Index of Nondurable Good Prices to the Standard and Poor's Stock Price Index averaged 1.234, with a standard deviation of .177. In 1974 and 1975 it rose to 1.82 and 1.89 , respectively. Again, this relative price behavior is clearly inconsistent with the contention that the ex ante real rate of interest fell in 1974 and 1975.

\section{CONCLUSIONS}

The method currently used to estimate the ex ante real rate of interest can lead to serious error. The error arises because this method requires the investigator to measure the expectations of market participants regarding the future rate of inflation. Unfortunately, since these expectations are never directly observed, the accuracy of the measurement is questionable.

Price expectations have typically been approximated by observing past rates of change in either the CPI or the GNP deflator. This method of approximation assumes, first, that expectations about the future rate of inflation depend largely on the past rate of inflation and, second, that the past rate of inflation is accurately reflected by the past rate of change in these price indices. This article has put aside the first issue and argues that past rates of change in the CPI and the GNP deflator may not accurately reflect the past rate of inflation.

We have shown that real interest rate changes themselves affect these indices. This occurs not only because these price indices give substantial weight to the prices of current consumption goods, as opposed to the prices of assets productive of future consumption (capital goods), but also becanse they reflect the impact of once-and-for-all changes in prices produced by changes in the real interest rate. Therefore, it is impossible when using this estimation procedure to separate changes in the real interest rate from changes in the rate of inflation. As a result, the method produces biased estimates of changes in the ex ante real rate of interest.

Furthermore, the direction of this error is predictable. In particular, when the real rate of interest rises, as in 1974 and 1975, the current method of estimation will understate the change in the real rate. Evidence from the mid-1970s suggests that estimates of the real rate based on the CPI failed to detect the direction of change in the real rate.

Because estimates of the real rate employing measures of anticipated inflation based on common price indices are suspect unless real rates are unchanging, their value is severely limited for use in formulating economic policy. Estimates of the ex ante real rate of interest are important to policymakers if they aid in distinguishing shifts in relative demands from shifts in aggregate demand (i.e, are able to actually detect changes in the real interest rate). However, the widely employed method of estimation breaks down precisely during periods in which the ex ante real interest rate changes. Consequently, estimated changes in the ex ante real rate of interest should be checked against the behavior of the relative prices known to depend upon the real rate prior to employing these estimates for economic policy purposes.

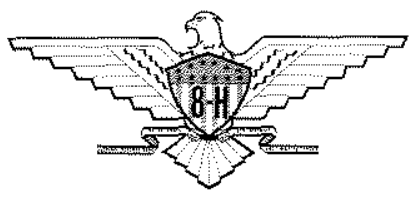

